УДК 370.182

Н. Ш. Закірова,

здобувач

(Житомирський державний університет імені Івана Франка)

zakirova.nataly@gmail.com

ORCID: 0000-0002-9666-122X

\title{
КОНЦЕПТУАЛЬНА МОДЕЛЬ ІНШОМОВНОЇ ПІДГОТОВКИ ДОРОСЛИХ
}

У статті розглядається розвиток моделі вивчення іноземної мови дорослими в рамках неформальної освіти в Украӥні, роль іноземної мови в неперервній освіті. Розроблена модель освіти ХХІ століття та вимоги до неї з точки зору ринку праџі сьогодення. Також в статті наведені приклади впровадження

сучасних ідей щзодо викладання іноземної мови серед дорослих на прикладі Центру іноземних мов

ЛІНГВО ЦЕНТР, м. Житомир. Новий погляд на освіту - це об'єктивно обумовлена необхідність. Нові завдання припускають зміни у вимогах до рівня володіння іноземною мовою, визначення нових підходів до відбору змісту і організації матеріалу, використання адекватних форм і видів контролю при різних варіантах його вивчення. В епоху глобалізацї істотно змінився сочіокультурний контекст вивчення іноземних мов в Украӥні. Значно зросла освітня і самоосвітня функції іноземних мов, їх підвищена значимість в школі, у вузі, на ринку праці в циілому, щуо спричинило за собою посилення мотивації у вивченні мов міжнародного спілкування.

Ключові слова: неперервна освіта, неформальна освіта, курси іноземних мов, освіта дорослих.

Постановка проблеми. Вивчення іноземної мови в сучасному світі - це один 3 найважливіших складових моментів в житті сучасної успішної людини. Знання іноземної мови не просто бажане, воно необхідне. Сьогодні з'являється все більше людей, які бажають володіти іноземною мовою, тому що це знання дає їм нові можливості і робить багатшими їх духовний світ.

В ідеалі впевнена, амбітна людина має володіти кількома іноземними мовами, постійно їх шліфувати і покращувати, тому що вивчення іноземних мов - зовсім не нудний процес. Це творче, захоплююче заняття, яке розвиває світогляд, дозволяє удосконалює логічне мислення, вміння висловлювати свої думки коротко і чітко.

Внаслідок глобальних змін у суспільному житті як в України, так і в усьому світі, змінилася роль іноземної мови в системі освіти. 3 простого навчального предмета вона перетворилася в базовий елемент сучасної системи освіти, в засіб досягнення професійної реалізації особистості.

Нова соціально-економічна і політична ситуація вимагає реалізації в суспільстві мовної політики в області іншомовної освіти, націленої на задоволення як громадських, так і особистих потреб по відношенню до іноземних мов. 3 реалізацією нової мовної політики пов'язано створення гнучкої системи вибору мов і умов їх вивчення, а також варіативної системи форм і засобів навчання, що відображають сучасний стан теорії та практики навчання іноземної мови. У зв'язку з цим вивчення іноземної мови в системі додаткової освіти набуло широких масштабів. Фахівці зі знанням іноземних мов потрібні в дедалі більшій кількості компаній і установ, і наявний попит на мови підштовхує викладачів і ділових людей до відкриття курсів іноземних мов, лінгвістичних центрів та інших навчальних закладів, що пропонують послуги з навчання іноземним мовам.

Аналіз останніх публікацій та досліджень. Аналіз останніх вітчизняних та зарубіжних публікацій дозволяє дійти висновку, що в сучасній науці приділяється велика увага зазначеним проблемам.

Саме тому багато досліджень присвячено саме розробці концептуальної моделі неформальної іншомовної освіти дорослих (Гусейнова Е. І., Петренко В. Л., Сігаєва Л. С., Сулаєва Н. В., Шапочкіна О. В.).

Метою статті є аналіз концептуальної моделі іншомовної освіти, яка допомогла дорослим освоювати та використовувати іноземну мову в рамках власного досвіду та вимог глобалізації.

Виклад основного матеріалу. Кожен бажаючий вивчити іноземну мову може вибрати доступний i найоптимальніший варіант для того, щоб вивчити ту мову, яка йому більше подобається. Сьогодні існує величезна кількість засобів вивчення іноземних мов. Пропонується індивідуальний підхід і унікальні розробки уроків іноземної мови. Звичайно, самостійно буває складно зорієнтуватися в потоці безкрайньої інформації і зробити правильний вибір в пропонованих сучасних методиках. Однак $є$ і більш стандартні методи вивчення мови - відвідування курсів, спеціалізованих навчальних закладів, нарешті, заняття з репетитором.

Основна перешкода на шляху тих, хто вирішив зайнятися вивченням мови, виникає ще до того, як вони приступили до самого вивчення - це психологічний бар'єр. Вивчення іноземної мови - це дуже складний, довгий і важкий процес. Дійсно, важко виділити багато часу, щоб вивчити мову швидко, та й зусиль доведеться докласти чимало. Але якщо знання мови для дорослої людини не необхідність, а лише 
приємне доповнення, то і вивчати їі потрібно по-іншому. Потроху, але кожен день, не поспішаючи і не ставлячи перед собою жорсткі терміни.

У наші дні роль освіти доволі висока, як ніколи в історії людства. Після того як ми залишили позаду століття промисловості та вступили в століття інформації, цінність освіти стала рости безперервно. Все питання в тому, чи відповідає рівень знань, який дає нам система освіти, вимогам нового світу?

У столітті промисловості людина могла отримати гарну освіту і на іiі основі будувати свою кар'єру. Зазвичай для досягнення успіху в житті не було необхідності в додатковому навчанні просто тому, що ситуація змінювалася не так швидко. Іншими словами, отриманих знань вистачало до кінця життя.

Однак сьогодні, коли мільйони людей готуються вийти на пенсію, багато хто 3 них виявляють, що їх освіти явно недостатньо для життя в умовах зміненого світу. Вперше в історії багато блискуче освічених людей відчувають ті ж економічні труднощі, що і люди майже неписьменні. Вони постійно стикаються 3 необхідністю придбання нових знань і навичок, без яких важко відповідати вимогам сучасного світу.

Будь-які зміни зазвичай зустрічаються в паніці. Однак за останні кілька років було багато випадків, коли люди скористалися можливостями, що виникають в період змін:

1. Вже сьогодні люди не завжди подають заяви про прийом на роботу, а виходять в Інтернет і беруть участь в конкурсах. В недалекому майбутньому бажаючим знайти гарантовану постійну роботу терміном більше ніж на рік доведеться погоджуватися на меншу зарплату.

2. Замість того, щоб сподіватися знайти хорошу роботу у великій компанії, все більше і більше студентів відкривають власний бізнес, не виходячи з кімнати в гуртожитку. У деяких університетах $€$ навіть спеціальна служба, яка допомагає студентам у створенні таких кімнатних підприємств нав'язуючи допомогу в організації бізнесу, вона явно прагне утримати молодих людей в стінах закладу.

3. У той же час половина працюючих України заробляють такі гроші, що їм вчасно звертатися за продовольчими талонами. Що ж буде з ними, коли вони будуть занадто старі для роботи? Чи можна вважати їх освіту достатньою?

4. Домашня форма навчання нікого більше не лякає. Сьогодні кількість дітей, які навчаються на дому, збільшується на 15 відсотків на рік.

5. Все більше батьків звертаються до альтернативних систем навчання і віддають дітей в приватні школи - наприклад Монтессорі - лише заради того, щоб позбавити їх від застарілої державної освітньої системи, яка не в силах задовольнити потреби нового покоління. Все більше батьків розуміють, що початкова освіта має таке ж значення для розвитку дитини, як і освіта в вищих навчальних закладах.

Прискорена інтенсивна програма навчання "Super Camp", що використовує методику занурення в середу і найсучасніші технічні засоби, допомагає поліпшити результати тестів і розвиває у підлітків упевненість в своїх силах. Вона спонсорується організацією "Learning Forum" і її можна знайти на сайті www.supercamp.com.

6. Простіше кажучи, вік інформації спричинить за собою економічні зміни, які зроблять прірву між бідними і багатими ще більше. Навколишній світ буде змінюватися швидше, ніж будь-коли. Вперше в історії ті, хто добре встигає в школі, можуть зіткнутися з тими ж економічними труднощами, що і ті, хто встигає погано.

Виникають питання, наскільки добре сьогодні освіта готує слухачів до майбутнього? Чи відповідає формальна освіта конкретним потребам сучасності? Що роблять батьки, якщо їхня дитина не любить школу або погано встигає? Чи є хороші оцінки гарантією майбутнього професійного та фінансового успіху? Чи потрібно взагалі дитині ходити в традиційну школу, щоб отримати ту освіту, яка їй потрібна?

Під впливом глобалізаційних процесів збільшується кількість моделей соціальної поведінки, і однією 3 нових умов соціальної мобільності і успішної адаптації в соціальному просторі стає володіння іноземними мовами. 3 розвитком міжнародних ділових контактів, освоєнням нових зарубіжних технологій і інтенсифікацією професійної діяльності в тісному контакті з іноземними фахівцями, а також у зв'язку з перспективою вступу України до Євросоюзу особливо зросла потреба України в фахівцях, які володіють іноземними мовами. Соціально активне населення все більше прагне використовувати відкритий для них міжнародний ринок праці, де в великій мірі на успіх впливає рівень володіння іноземними мовами [1: 3]. Все це - стрімке входження України в світову спільноту, значні зміни в політиці, економіці, культурі, змішання і переміщення народів і мов, зміна відносин між українцями i іноземцями, абсолютно нові цілі спілкування - призводить до закономірних результатів: в Україні помітний небувалий попит на вивчення іноземних мов.

Мовна глобалізація виходить з того, що мова є засобом людського спілкування і спонукає розвиток багатомовності [1: 5]. Політичні, соціально-економічні та культурні зміни в Україні в 90-х рр. істотно розширили функції іноземної мови. Включення України в світовий ринок, розширення співпраці із закордонними країнами значно збільшили можливість контактів для представників різних соціальних і вікових груп. З'явилися реальні умови для отримання освіти і роботи за кордоном, для просування українських товарів і послуг на світовий ринок, для обміну інформації студентами, школярами, фахівцями. Внаслідок цього змінилася роль іноземної мови в суспільстві, і з навчального предмета він 
перетворився в базовий елемент сучасної системи освіти, в засіб досягнення професійної реалізації особистості.

Новий підхід до освіти передбачає, що вона більш не повинна замикатися виключно на школі або вузі. Навпаки, вона повинна включати дозвілля, сім'ю, роботу, суспільство, міжнародні відносини, навколишнє середовища і т. д. Вона вимагає, щоб люди стали самі собі вчителями і усвідомили свій інтелектуальний, емоційний і творчий потенціал [2: 39].

Для того щоб такий тип освіти став можливий і не здавався утопією, потрібні нові освітні структури $і$ змінений образ думок. В даному випадку система безперервної мовної освіти повинна бути побудована таким чином, щоб своєчасно і гнучко задовольняти освітні та професійні потреби особистості. Найважливішим компонентом даної системи є, як уже було відзначено, іiі непереривність, тобто відкритість для входження будь-якого індивіда, який бажає придбати відповідний рівень мовної освіти або придбати іншу спеціалізіцію, на будь-якому етапі їі життєдіяльності [3].

Освіту ХХІ ст. повинні відрізняти такі риси [3]:

- загальнодоступність, забезпечення передумов і гарантій якісної освіти для всіх;

- різноманіття, створення умов якісної освіти для кожного;

- безперервність, розвиток системи швидко оновлюваної освіти протягом усього життя;

- фундаментальність і глибина основ початкової, основної, загальної середньої та професійної освіти;

• практична спрямованість освіти;

- адекватність освіти, іiі відповідність потребам і задачам розвитку економіки, культури, науки i технологій;

- міжнародний характер освіти

Щоб реалізувати ці ідеї, необхідно істотно посилити підготовку педагогічного персоналу, значно підвищити оплату його праці, настільки ж важливо створити умови для підвищення здорової підприємницької активності навчальних закладів усіх форм власності, розширити ринок освітніх, інформаційних та науково-технічних послуг, що вони надають.

Посилення конкуренції за різними напрямками є невід'ємним фактором глобалізації та характеризує сучасний розвиток світового ринку освіти. Зростає конкуренція між класичними університетами, що належать державі, та альтернативними вищими навчальними закладами типу віртуальними, корпоративними освітніми асоціаціями, які знаходяться в руках приватного капіталу. Збільшується боротьба за студентів між вузами всередині країни і на міждержавному рівні. Глобалізація ринку стала можлива завдяки лібералізації ринків освітніх послуг [4: 26].

"Конкурентоспроможність системи освіти може бути досягнута на основі реалізації ефективної стратегії експорту освітніх послуг, які для багатьох країн $є$ прибутковою галуззю економіки, важливим напрямком політики і показником соціального і культурного розвитку, в умовах інтернаціоналізації освіти, що забезпечує підвищення його рівня і якості" [5: 11].

"Ринок міжнародної освіти розвивається дуже динамічно. Його сумарні фінансові показники, включаючи мовні курси для іноземних громадян, середню та вищу освіту, додаткову професійну освіту і т.д., вже перевищують 100 млрд. доларів США, а загальна кількість іноземців, щорічно виїжджають 3 різними освітніми цілями за рубіж, досягає 5 млн. Тому в США експорт вищої освіти (за програмами третинного рівня) вважається п'ятою за значимістю галуззю експортних послуг, в Австралії - четвертою експортною галуззю і т.д." [6: 23].

"Великим сегментом ринку освітніх послуг є і курси іноземних мов для громадян різних країн. Так, в 2005 р. для вивчення англійської мови в ряд англомовних країн світу (Великобританія, Канада, США, Ірландія, Австралія, Мальта, Нова Зеландія, ПАР) приїжджали 1,3 млн. осіб. Сукупні доходи тільки від оплати за їх навчання у приймаючих країнах склали близько 10 млрд. доларів США (без обліку витрат іноземців на проживання в середньому протягом 2-3-х місяців, їх харчування і т.д.). Збільшується також кількість іноземних громадян, які вивчають іспанську, французьку, німецьку мови. Надзвичайно зріс в світі попит до китайської мови і культури, породжений економічними успіхами цієї країни. За даними 3 китайських джерел, кількість тих, хто вивчає китайську мову в усьому світі досягає 40 млн. осіб, в тому числі в США чисельність вивчаючих китайську становить 700 тис. осіб, в Канаді - понад півмільйона і т.д. У 2009 р. в 88 країнах світу діяли 282 Інститутів Конфуція, а також 262 школи / класів Конфуція, створених урядом КНР для поширення китайської мови і культури за кордоном, а в сам Китай 3 метою вивчення (в тому числі поглибленого) мови щорічно приїжджає понад 140 тисяч іноземців" [6: 21].

Одночасно з кількісним зростанням повинне початися якісне зростання ринку. Це відноситься і до структури попиту на освітні послуги, яка стає все більш кваліфікованою, і до структури пропозиції. Або освітні установи повинні почати розглядати свої послуги як "звичайний продукт", із застосуванням всіх інструментів комплексу маркетингу, або - поступово покинути ринок [7: 10].

Для успішного функціонування системи безперервної мовної освіти важливим моментом є збір даних 3 торгівлі освітніми послугами, в даному випадку - іноземними мовами. Доцільно постійно проводити 
вивчення наявних пропозицій, так як володіння інформацією допомагає виробляти правильну стратегію розвитку і стимулює до підвищення якості пропонованих послуг.

Звичайно, хотілося б прагнути до більш детального і скоєного збору статистичної інформації. Проте існує проблема обмеженого охоплення вузів, лінгвістичних центрів та інших організацій, що займаються наданням освітніх послуг з іноземних мов, статистикою. У своїй роботі ми спираємося на досвід окремих вузів України i регулярно вивчаємо ринок України, що дозволяє нам відстежувати ціни i тип пропонованих освітніх послуг і сприяє виявленню нових тенденцій розвитку освіти. Основним джерелом інформації служать Інтерні-сайти установ та реклама освітніх послуг будь-якого виду (газета, журнал, 3МI, радіо, телебачення та т.д.). Різноманітність типів і моделей іншомовної освіти ускладнює завдання збору подібних даних і їх аналізу, вивчення динаміки розвитку освіти і зіставлення систем навчання різних вузів або організацій в сфері додаткової освіти.

Багато маркетингових методів - реклама, просування товарів і послуг, аналіз наявних покупців i конкурентів - використовуються вже кілька тисяч років.

Основне призначення послуг - задовольняти потреби населення, що постійно змінюються. Саме в силу швидкого збільшення кількості нових потреб сфера послуг в останні десятиліття зазнає значного розвитку. За прогнозами вчених, у майбутньому саме послуги, а не матеріальні товари будуть користуватися підвищеним попитом [8]. Тому вони вимагають великого контролю якості, довіри до постачальника і здатності пристосовуватися до запитів споживачів.

В даний час ринок освітніх послуг тісно підійшов до ситуації, коли [8]:

- оформився диференційований попит на освітні послуги;

- склалася розвинена структура ринку освітніх послуг;

• обсяг пропозиції став перевершувати платоспроможній попит;

- установам освіти доводиться розширювати перелік пропонованих на ринку освітніх послуг 3 метою "виживання".

Ключовим фактором успіху будь-якої організації є знання того, як споживач приймає рішення про покупку тих чи інших товарів і послуг, що їм керує або що обмежує вибір рішення i, нарешті, як організація може вплинути на поведінку своїх споживачів 3 найбільшою ефективністю. На поведінку споживача освітньої послуги впливають психологічні, соціологічні, економічні фактори, потреба щодо освіти, макросередовище освіти, мікросередовище освітнього закладу, якість освіти, методи просування освітніх послуг [8].

Світовий ринок освітніх послуг умовно об'єднує в собі кілька сегментів, основними 3 яких $є$ мовні курси, шкільне навчання, вища освіта, додаткова професійна освіта і ін. Слід зазначити, що всі сегменти світового ринку освітніх послуг пов'язані між собою [4: 12]. Проте на ринку освітніх послуг вони представлені по-різному.

Найбільш популярним сегментом є мовні курси. Це так би мовити основний елемент освітніх послуг 3 іноземних мов, на базі якого шикуються інші сегменти і створюються цілі освітні системи. Аналіз сайтів із іноземних мов показав, що курси пропонуються як державними, так і недержавними установами. Але далеко не завжди пропоновані курси складаються в продуману, науково обгрунтовану систему освітніх послуг з іноземних мов, що враховує останні досягнення і вимоги часу. В даному випадку мова не йде про застосування популярних у викладанні іноземних мов зарубіжних методик або навчальних посібників. Йдеться про такі значущі концепції, як, наприклад, концепція безперервної освіти, яка послужила поштовхом до створення багаточисельних проектів i проведення в області освіти експериментів у всіх частинах світу, і тим самим зіграла важливу роль у розвитку сучасного погляду на освіту [3].

Інтернет буквально рясніє оголошеннями про курси іноземних мов. Більшість 3 них не викликають особливого інтересу з наукової точки зору, так як $є$ лише комерційною пропозицією. Те ж можна сказати і про лінгвістичні центри. Далеко не всім 3 них вдалося пройти шлях від маленької компанії, створеної 3 нуля, до великої організації, яку знають і гідно оцінюють багато тисяч вдячних клієнтів в різних регіонах країни. I лише деякі 3 них пропонують добре продумані моделі безперервного навчання іноземним мовам. Наприклад, хотілось би особливо зупинитися на діяльності лінгвістичного центру ЛІНГВО ЦЕНТР (Житомирська область), який існує на ринку освітніх послуг з іноземних мов вже більше 6 років. У центрі викладають основні європейські мови (англійська, французька, німецька, іспанська, польська, італійська), а також українську та російську мови для іноземців. Введено навчання східних мов: китайська, японська, арабська.

Головне завдання центру - навчання іноземним мовам дітей і дорослих, проведення науководослідницької роботи, пов'язаної з особливостями навчання дітей і дорослих не тільки в Україні, але і закордоном. Центр має договори з провідними зарубіжними університетами Європи і Америки. У зв'язку 3 цим центр приділяє пильну увагу професійній підготовці вчителя.

Підвищення кваліфікації носить системний характер і передбачає з боку викладачів участь в курсах, семінарах, лінгвометодичних форумах, відвідування уроків своїх колег в ЛІНГВО ЦЕНТРІ і в 
навчальних центрах в Україні і закордоном, складання спільних програм, проектів та ін. Крім цього, практикується запрошення відомих українських і зарубіжних вчених і фахівців для проведення курсів та семінарів на базі лінгвістичного центру.

На особливу увагу заслуговує той факт, що ЛІНГВО ЦЕНТР активно готує кваліфікованих спеціалістів для себе сам. Більш того, тут практикуються стимулюючі надбавки, премії всім, хто успішно підвищує кваліфікацію. Центр виходить 3 того, що викладач іноземних мов повинен бути конкурентноздібним і сприйнятливим до сучасних технологій, Інтернету, комп'ютерів і т.д. Модернізація системи освіти передбачає модель фахівця, готового до інноваційної, творчої самореалізації у професійній діяльності. Сучасному спеціалісту для того, щоб справлятися з покладеними на нього функціями, для його професійного розвитку та кар'єрного зростання також необхідне креативне мислення.

Науковий напрямок діяльності лінгвістичного центру ЛІНГВО ЦЕНТР пов'язаний з методологічними проблемами навчання іноземним мовам, проблемами білінгвізму, лінгводидактичними, лінгвокраїнознавчими і психологічними аспектами в навчанні іноземним мовам дошкільнят, школярів і дорослих.

У центрі впроваджуються найостанніші досягнення української і зарубіжної науки, спрямовані на підвищення якості навчання іноземним мовам, розвиток особистості дітей засобами іноземної мови, формування нового покоління молоді, яка активно володіє двома-трьома іноземними мовами.

Відмінною особливістю ЛІНГВО ЦЕНТРУ $є$ те, що щорічно учні і дорослі проходять міжнародну сертифікацію, складають іспити і отримують міжнародні сертифікати.

Аналіз діяльності лінгвістичного центру ЛІНГВО ЦЕНТР ще раз показує, що головне в діяльності будь-якої установи - якісна, ініціативна, креативна і захоплююча робота всього колективу, високий професіоналізм всіх членів команди, впровадження інновацій і нових технологій в навчальний процес i, звичайно, віра в спільну справу.

Нові інформаційні технології знаходять широке застосування в навчанні і самостійному вивченні іноземних мов. В Інтернеті $\epsilon$ чимало проектів, які пропонують інтерактивні програми вивчення іноземних мов. Це, наприклад, програма LinguaLeo, успішний російський проект, в якому закладена ігрова форма вивчення іноземної мови; програма Kimir.org, пропонує вивчення через невеликі ролики 3 популярних фільмів і призначена для тих, хто ще не може дивитися фільми цілком; програми сайту freelanguage.org або сайту englishpod.com А також такі сайти, як puzzle-english.com, на якому мова вивчається у вигляді пазлів до відео роликів, та english-e-books.net, де можна знайти цікаві адаптовані та неадаптовані книги в аудіо та пдф форматі, MyEnglishPlatform від Pearson - електронний ресурс, збагачений вправами та заняттями для тих, хто бажає цікаво та швидко підвищити рівень англійської мови.

Висновки та перспективи дослідження. Аналізувати діяльність лінгвістичних центрів не тільки цікаво, а й корисно. Такий підхід пропонує широкий спектр освітніх послуг, починаючи від дітей до просунутих в роках дорослих, а з іншого боку, зробити для себе багато важливих відкриттів, які допоможуть вдосконалювати роботу викладача іноземних мов і зробити її більш ефективною.

\section{СПИСОК ВИКОРИСТАНИХ ДЖЕРЕЛ ТА ЛІТЕРАТУРИ}

1. Саєнко Н. С. Іншомовна освіта студентів у форматі розвиваючого навчання / Н. С. Саєнко. -Суми : Вид. СумДПУ ім. А. С. Макаренка, 2011.-302 с.

2. Leclerc G. Non-Stop Learning (A Utopia for our times?) / G. Leclerc // UNESCO Courier. - Feb 1991. - 39 p.

3. Knibbeler W. The Explorative Creative Way. Implementation of a Humanistic Language Teaching Model/ W. Knibbeler. - Tubingen : Gunter Narr Verlag, 1989.

4. Румянцев А. П. Світовий ринок послуг : [навчальний посібник] / А. П. Румянцев, Ю.О.Коваленко. - К. : Центр навчальної літератури, 2006. - 456 с.

5. Лук'янова Л. Б. Концепція освіти дорослих в Україні / Л. Б. Лук'янова // Зб. наукових праць "Освіта дорослих : теорія, досвід, перспективи". 2011. - № 7. - С. 8-21.

6. Місечко О. Є. Європейські орієнтири в розробці стандартів професійно-педагогічної підготовки майбутніх учителів іноземних мов // Шлях освіти. - 2012. - № 1. - С 19-23.

7. Мусійчук С. М. Оптимізація процесу викладання іноземних мов у ВНЗ з використанням синергетичного підходу. Практичні рекомендації викладачам іноземних мов / С. М. Мусійчук. - К. : НУБіП України, 2011. $58 \mathrm{c}$.

8. Paye J. Strategies for a Learning Society / J. Paye // OESD Observer. - April-May. - 1996. - No 199.

\section{REFERENCES (TRANSLATED \& TRANSLITERATED)}

1. Saienko N. S. Inshomovna osvita studentiv u formati rozvyvaiuchoho navchannia [Students' Foreign Language Education in the Format of Developmental Education]/ N. S. Saienko. - Sumy: Vyd. SumDPU im. A. S. Makarenka, 2011. - $302 \mathrm{p}$.

2. Leclerc G. Non-stop learning (A Utopia for our times?) / G. Leclerc // UNESCO Courier. - Feb 1991. -39 p.

3. Knibbeler W. The Explorative Creative Way. Implementation of a Humanistic Language Teaching Model / 
W. Knibbeler. - Tubingen : Gunter Narr Verlag, 1989.

4. Rumiantsev A. P. Svitovyi rynok posluh [Global Services Market] : [navchalnyi posibnyk] / A. P. Rumiantsev, Y. O. Kovalenko. - K. : Tsentr navchalnoii literatury, 2006. -456 p.

5. Lukianova L. B. Kontseptsiia osvity doroslykh $\mathrm{v}$ Ukraini [The Concept of Adult Education in Ukraine] / L. B. Lukianova // Zb. naukovykh prats' "Osvita doroslikh : teoriia, dosvid, perspektyvy" [Collection of Scientific Works "Adult Education : Theory, Experience, Perspectives"]. - 2011. - № 7. - Pp. 8-21.

6. Misechko O. Ye. Yevropeiski oriientyry v rozrobtsi standartiv profesiino-pedahohichnoi pidhotovky maibutnikh uchyteliv inozemnykh mov [European Benchmarks in the Development of Professional Pedagogical Training Standards for Future Foreign Language Teachers] / O. Ye. Misechko // Shliakh Osvity [Way of Education]. -2012. - № 1. - Pp. 19-23.

7. Musiichuk S. M. Optymizatsiia protsesu vykladannia inozemnykh mov u VNZ z vykorystanniam synerhetychnoho pidkhodu. Praktychni rekomendatsii vykladacham inozemnykh mov [Process Optimization for Teaching Foreign Languages in Higher School with the Use of the Synergistic Approach. Practical Avice to Teachers of Foreign Languages] / S. M. Musiichuk. - Kyiv : NUBiP Ukrainy, 2011. - 58 p.

8. Paye J. Strategies for a Learning Society / J. Paye // OESD Observer. - April-May. - 1996. - No 199.

\section{Закирова Н. Ш. Концептуальная модель иноязычной подготовки взрослых.}

В статье рассматривается развитие модели изучения иностранного языка взросльми в рамках неформального образования в Украине, роль иностранного языка в непрерывном образовании.

Разработана модель образования ХХІ века и требования к ней с точки зрения рынка труда сегодняшнего дня. Также в статье приведены примеры внедрения современных идей относительно преподавания иностранного языка среди взрослых на примере Центра иностранных языков ЛИНГВО ЦЕНТР, г. Житомир. Новый взгляд на образование - это объективно обусловленная необходимость.

Новые задачи предполагают изменения в требованиях к уровню владения иностранным языком, определение новых подходов к отбору содержания и организации материала, использованию адекватных форм и видов контроля при разных вариантах его изучения. В эпоху глобализации существенно изменился сочииокультурный контекст изучения иностранных языков в Украине. Значительно возросла образовательная и самообразовательная функиии иностранных языков, их повышенная значимость в школе, в вузе, на рынке труда в целом, что повлекло за собой усиление мотиващии в изучении языков международного общения.

Ключевые слова: непрерывное образование, неформальное образование, курсы иностранных языков, образование взросльх.

\section{Zakirova N. Sh. Conceptual Model of Foreign Language Training for Adults.}

The article discusses the development of the model of foreign language learning by adults in non-formal education in Ukraine, the role of foreign language in the long-life education. The model of education in the XXI century and the requirements based on the employment market today were also considered hereof. The article also provides examples for modern ideas implementation on the foreign language teaching among adults in the

Center of Foreign Languages LINGVO CENTRE, Zhytomyr. A new view of education is objective due to the need. New challenges involve changes in the level of foreign language proficiency, identification of new approaches to content and material selection, use of suitable forms and types of control in different study alternatives. In the era of globalization socio-cultural context of foreign language learning in Ukraine has

significantly changed. Moreover educational and self-educational function of foreign languages, their importance in school, in high school, within the employment market as a whole increased. This resulted in high motivation to the learning of foreign languages in international communication. Due to global changes in public life in Ukraine and worldwide, has changed the role of foreign language in the education system. From a simple school subject it has become a basic element of modern education system into a means of achieving professional development of the individual.

New socio-economic and political situation requires implementing a new language policy for the society in the field of foreign language education, aimed at meeting both social and personal needs in relation to foreign languages. Implementing the new language policy related to the establishment of flexible languages choice and the conditions of their study, as well as a flexible system of forms and means for education reflect the current state of the theory and practice of foreign language teaching. In this regard, learning a foreign language in the system of extra education acquired a wide scale. Specialists with knowledge of foreign languages required in an increasing number of companies and institutions, and the existing demand for languages encourages teachers and business people to open foreign language courses, language centres and other educational institutions that offer services for learning foreign languages. This article considers new approaches and general attitude towards teaching foreign languages to adults, how to motivate them and improve their results.

Key words: long-life education, non-formal education, foreign language course, adult education. 